\title{
Expression of Maternal Embryonic Leucine Zipper Kinase (MELK) Correlates to Malignant Potentials in Hepatocellular Carcinoma
}

\author{
KIYOKAZU HIWATASHI ${ }^{1}$, SHINICHI UENO ${ }^{2}$, MASAHIKO SAKODA ${ }^{1}$, SATOSHI IINO ${ }^{1}$, \\ KOJI MINAMI ${ }^{1}$, KEIICHI YONEMORI ${ }^{1}$, YUKA NISHIZONO ${ }^{1}$, HIROSHI KURAHARA ${ }^{1}$, \\ YUKO MATAKI $^{1}$, KOSEI MAEMURA ${ }^{1}$, HIROYUKI SHINCHI $^{3}$ and SHOJI NATSUGOE $^{1}$ \\ ${ }^{1}$ Department of Digestive Surgery, Breast and Thyroid Surgery Graduate School of \\ Medical and Dental Sciences Kagoshima University, Kagoshima, Japan; \\ ${ }^{2}$ Department of Clinical Oncology, Graduate School of Medical and Dental \\ Sciences Kagoshima University, Kagoshima, Japan; \\ ${ }^{3}$ Faculty of Medical School of Health Sciences, Graduate School of Health \\ Sciences Kagoshima University, Kagoshima, Japan
}

\begin{abstract}
Background/Aim: Maternal embryonic leucine zipper kinase (MELK) is categorized as a member of AMPactivated protein kinase families. Various MELK-associated cellular and biological processes affect multiple stages of tumorigenesis. The aim of the present study was to clarify the relationship between MELK expression and hepatocellular carcinoma (HCC) clinicopathological features. Materials and Methods: In thirty conserved frozen primary $\mathrm{HCC}$ and nonHCC samples MELK mRNA expression was examined by quantitative real-time polymerase chain reaction $(P C R)$. Results: HCC tissues exhibited significantly higher expression levels compared to non-cancerous tissues. MELK expression had a statistically parallel correlation between tumor diameter and protein induced by vitamin $K$ absence or antagonist II (PIVKA-II). The overall survival $(O S)$ and recurrence-free survival (RFS) of the low MELK mRNA expression group was significantly longer than that of the high MELK $m R N A$ expression group. Conclusion: MELK expression in HCC is extremely intense compared to its expression reported in other types of cancer. MELK could be a promising effective tumor marker of HCC and further consideration is needed.
\end{abstract}

Hepatocellular carcinoma (HCC) is the most common type of liver cancer. Currently, HCC is the third most deadly and fifth

Correspondence to: Shinichi Ueno, Graduate School of Medical and Dental Sciences Kagoshima University, Sakuragaoka 8-35-1 Kagoshima, 890-8520, Japan. Tel: +81 992755361, Fax: +81 992657426, e-mail: ueno1@m.kufm.kagoshima-u.ac.jp

Key Words: HCC, MELK, tumor marker, PCR. most common cancer worldwide $(1,2)$. Chronic infection with hepatitis $\mathrm{B}$ virus (HBV), which affects approximately $5 \%$ of the global population, or hepatitis $\mathrm{C}$ virus (HCV), affecting approximately $2 \%$ of the global population, are risk factors for the development of HCC (3). A large number of patients are infected with hepatitis viruses in Japan and HCC is the fourth most deadly and sixth most common cancer according to Japanese vital statistics conducted in 2008 (4).

Maternal embryonic leucine zipper kinase (MELK) is categorized as a member of both the sucrose-non-fermenting (snf) 1 and the AMP-activated protein kinase (AMPK) families. This is because of the presence of a conserved serine/threonine kinase domain in the $\mathrm{N}$-terminal region also known as murine protein serine-threonine kinase 38 (MPK38) (5) or Eg3 protein (6). Unlike other snf1/AMPK family members, MELK is activated by in vitro autophosphorylation (7). Various MELKassociated cellular and biological processes, including cell cycle, cell proliferation, apoptosis, gene expression, hematopoiesis and oncogenesis are involved in multiple protein interactions that affect multiple stages of tumorigenesis (8).

There is a wide expression pattern of MELK in human adult tissues, including the colon, esophagus, lymphoid tissue, skin, small intestine, soft tissue, testis, thymus and spleen (9). However, MELK is not present in the central nervous system, muscles, kidneys or liver (9). Regarding the relationship between cancer and MELK, there was a report that MELK mRNA levels were elevated in colon, breast, ovary and lung cancer samples compared to those in non-cancerous samples from the same organs. Additionally, knockdown of $M E L K$ decreased proliferation and anchorage-independent growth in vitro, as well as tumor growth in a xenograft model (9). Some studies have demonstrated a correlation between MELK 
expression and tumor malignancy grade for astrocytoma (10), breast cancer (11) and prostate cancer (12), as well as radiation and chemoresistance in colorectal cancer (13).

Therefore, the objective of this study was to clarify the relationship between MELK expression and HCC clinicopathological features.

\section{Materials and Methods}

Patients and study groups. We studied thirty conserved frozen primary $\mathrm{HCC}$ and non-HCC samples that were obtained via hepatic resection from 2008 to 2014 and pathologically diagnosed in our Department. Thirty paired samples that did not contain degraded RNA were used in this study. A group of thirty patients (23 men and seven women, average age $=67.3$ years) were included in the present study.

This study was approved by the Institutional Review Board of Graduate School of Medical and Dental Sciences Kagoshima University, Japan, and conducted according to the ethical guidelines of the Declaration of Helsinki. Written informed consent was given by each patient.

Clinicopathological factors. Clinicopathological factors selected for evaluation included fatty liver, diabetes mellitus, alcohol consumption and preoperative laboratory values (such as indocyanine green (ICG) retention rate at 15 min (ICGR15) value and tumor markers, including $\alpha$-fetoprotein (AFP) and protein induced by vitamin $\mathrm{K}$ absence or antagonists-II (PIVKA-II) levels). A diagnosis of diabetes mellitus was based on the results of a 75-g oral glucose tolerance test or a random blood glucose measurement $>200 \mathrm{mg} / \mathrm{dl}$. Excessive alcohol consumption was defined as an average daily consumption of an amount equivalent to $80 \mathrm{~g}$ of pure ethanol for more than 10 years. Diabetes mellitus patients enrolled in the study included patients whose symptoms were medically wellcontrolled. Histopathological diagnosis was based on the evaluation of tumor size, number of tumor nodules, lymph node metastasis and infiltration of blood vessels (portal vein, hepatic artery and/or vein). HCC staging was conducted using The General Rules for the Clinical and Pathological Study of Primary Liver Cancer (14).

Cells and cell culture. Hepatoma cell lines HepG2, HuH7 and Li7 were provided by the Cell Resource Center for Biomedical Research Institute of Development, Aging, and Cancer at Tohoku University (Sendai, Japan). HepG2 were cultured with DMEM and HuH7, and Li7 were cultured with RPMI.

Quantitative real-time polymerase chain reaction (PCR). For reverse-transcription PCR and quantitative real-time PCR, total RNA was extracted from $30 \mathrm{mg}$ frozen tissues using a phenol extraction method. For cDNA synthesis, the RNA samples $(1 \mu \mathrm{g})$ were converted into cDNA by reverse transcription using random primers (TAKARA, Siga, Japan) according to the manufacturer's instructions. To estimate the mRNA expression levels of several genes quantitatively, PCR amplification was performed using a Light-Cycler system (Roche, Mannheim, Germany) and the SYBER select master mix (Waltham, MA, USA). Primers were as follows: MELK: 5'-GCC TGC CAT ATC CTT ACT GG-3', 5'-TGG CTG TCT CTA GCA CAT GG-3', HPRT: 5'-GAC CAG TCA ACA GGG GAC AT-3', 5'-CTG CAT TGT TTT GCC AGT GT-3'. Reaction conditions were performed at an initial incubation at $95^{\circ} \mathrm{C}$ for $30 \mathrm{~s}$, followed by 40 cycles at $95^{\circ} \mathrm{C}$ for $5 \mathrm{~s}$ for denaturation, $60^{\circ} \mathrm{C}$ for 30 $\mathrm{s}$ for annealing of the primers and $54^{\circ} \mathrm{C}$ for $10 \mathrm{~s}$ for annealing and extension. Melting curves were obtained according to the protocol under the following conditions: $0 \mathrm{~s}$ denaturation period at $95^{\circ} \mathrm{C}$, starting temperature of $65^{\circ} \mathrm{C}$, end temperatures of $95^{\circ} \mathrm{C}$ and a rate of temperatures increase of $0.1^{\circ} \mathrm{C} / \mathrm{s}$. The quantitative value of the target gene (MELK mRNA) in each sample was normalized using hypoxanthine-guanine phosphoribosyltransferase (HPRT) expression as an internal control. The quantitative real time-PCR assay was performed twice and the mean value was calculated. Finally, the mRNA expression ratio of cancerous $(\mathrm{C})$ to non-cancerous $(\mathrm{N})$ tissues was calculated using the following formula: $R=\log \{$ MELK (C)/HPRT (C) $\}, R=\log \{\operatorname{MELK}(\mathrm{N}) / \operatorname{HPRT}(\mathrm{N})\}$. All experiments were performed twice to confirm reproducibility.

Statistical analyses. An unpaired t-test was used to evaluate continuous variables. The overall survival (OS) was calculated from the date of resection to the date of death regardless of the cause of death. The recurrence-free survival (RFS) was calculated from the date of resection to the date that the tumor recurrence was diagnosed or from the date of the resection to the last visit if the recurrence was not diagnosed. The cumulative OS and RFS rates were calculated using the Kaplan-Meier method and tested using the log-rank test. Data are presented as a mean \pm standard deviation. A probability $(p)$ value of $<0.05$ was considered to be statistically significant. Statistical analyzes were performed using the SPSS statistical software package (version 23; SPSS Inc., Chicago, IL, USA).

\section{Results}

Comparison of MELK MRNA expression between cancerous samples, non-cancerous samples, and HCC cell lines. Using real-time PCR, MELK and HPRT mRNA expression levels were examined between the three HCC cell lines (Huh7, HepG2 and Li7), as well as cancerous and non-cancerous tissues from two patients (Figure 1). Three cell lines and two cancer tissues highly expressed $M E L K$ mRNA. However, $M E L K$ mRNA expression was lower in the two noncancerous tissues.

Quantitative MELK MRNA expression in HCC and noncancerous lesions. Comparing the quantitative expression of $M E L K$ mRNA in paired cancer and non-cancerous tissues from 30 cases, HCC tissues exhibited significantly higher expression levels compared to non-cancerous tissues ( $p<0.001$, Figure 2$)$.

Relationship between MELK MRNA expression and clinicopathological features. To elucidate the biological significance of MELK expression in HCC, we compared the levels of $M E L K$ mRNA expression with the clinicopathological features of 30 patients. MELK mRNA expression was significantly higher in the tumor size $\geq 3.75 \mathrm{~cm}$ ( $p=0.015$; Table I), the PIVKA II $\geq 40 \mathrm{mAU} / \mathrm{ml}$ ( $p=0.047$; Table I), the advanced tumor stages ( $p=0.005$; Table I) and had a tendency to be lower in simple nodular types of tumors ( $p=0.088$, Table I) within the pathological parameter. 


\section{Real Time - PCR}

HPRT MELK

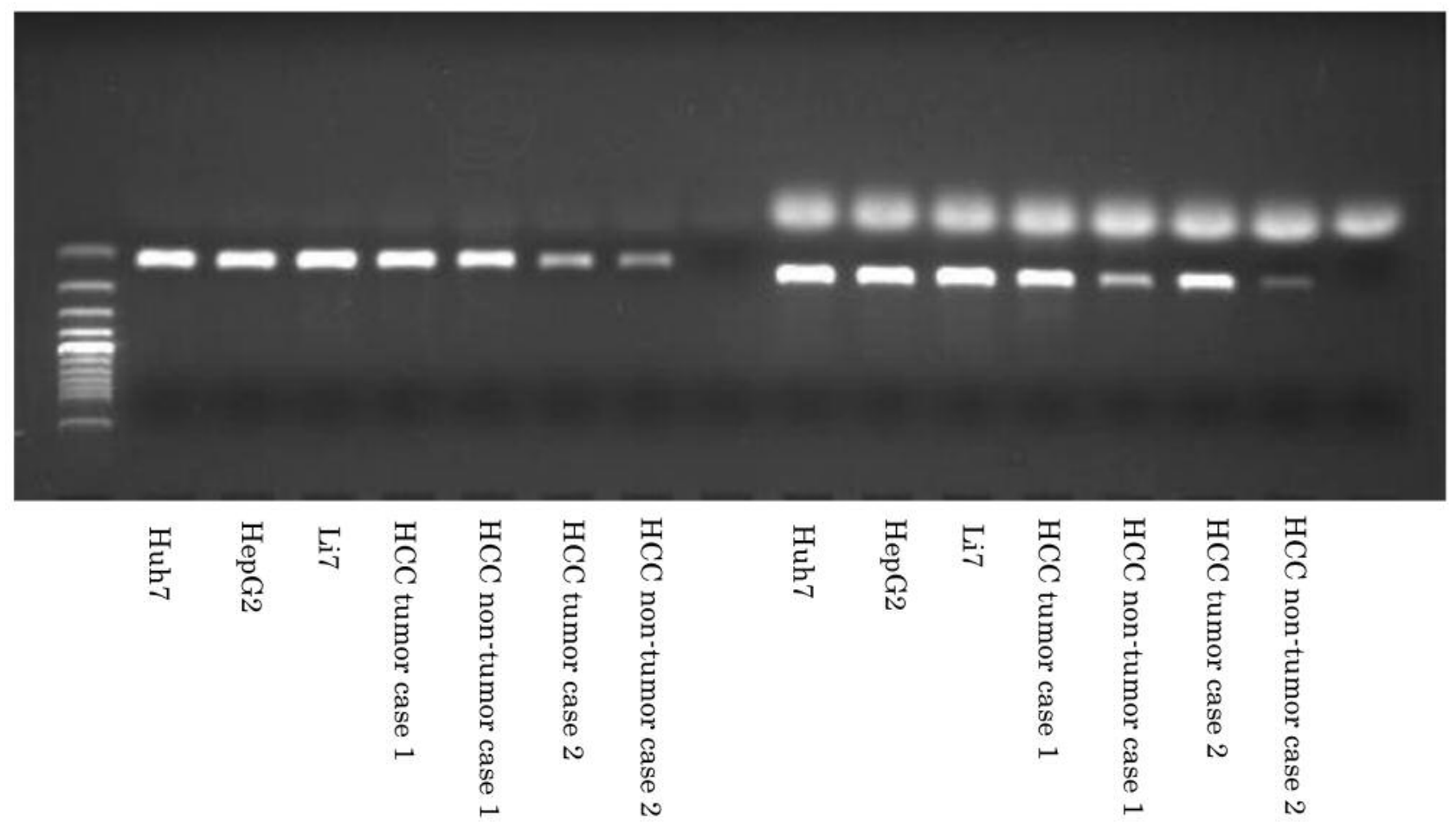

Figure 1. MELK and HPRT mRNA expression levels were examined between the three HCC cell lines (Huh7, HepG2 and Li7), as well as cancerous and non-cancerous tissues from two patients. Three cell lines and two cancer tissues highly expressed MELK mRNA. However, MELK mRNA expression was lower in the two non-cancerous tissues.

Comparison of $O S$ and RFS between MELK $m R N A$ high and low groups. We further investigated the correlation between the relative $M E L K$ mRNA levels, as well as the OS and RFS of patients with HCC. When we set a cut-off value of 0.7 in this examination, OS (median survival=65.5 months $v s .34 .9$ months; $p=0.019$; Figure 3 ) and RFS (median survival=42.3 months vs. 11.0 months; $p=0.012$; Figure 4) of the low $M E L K$ mRNA expression group was significantly longer than that of the high $M E L K$ mRNA expression group.

\section{Discussion}

MELK was identified in mice using differential display analyses of cDNA libraries from unfertilized eggs and preimplantation embryos (15). MELK is expressed across a wide range of embryonic stages and the gene has been shown to play an important role in preimplantation embryonic development (16).

MELK was reported to bind to c-Jun (17), p53 (18), tumor necrosis receptor-associated factor (19), Daxx (20), thioredoxin $(21,22)$, glutaredoxin $(23)$, heat shock protein
72 (24), Raf-1 (21), FOXM1 (25) and Akt/PKB (26). In particular, c-Jun is a family of MAP kinases, including the c-Jun NH(2)-terminal kinases (JNKs). The JNK pathway induces cell proliferation and apoptosis. Tumor-specific MELK interaction with c-Jun can contribute to cellular proliferation and selective apoptosis (27). Moreover, MELK associated with p53 could enhance p53-mediated cell cycle arrest and apoptosis (18).

Concerning the cell cycle, MELK-regulated phosphorylation of FOXM1, a master regulator of cell-cycle progression (27), facilitated FOXM1 transcriptional activity. Moreover, MELK expression was similar to that of cyclin A, cyclin B and CDK1 and 4 for mitotic progression $(28,29)$ and was co-regulated with mitosis-phase regulatory protein ASPM and Aurora kinase B (30). With respect to the regulation of apoptosis, MELK was associated with resistance to apoptosis through inhibition of Bcl-G (31) and its regulation of p53 activity (32).

There have been some reports that MELK was expressed in cancer stem cells or initiating cells. High levels of MELK expression in mammary tumors resulted in a significant 


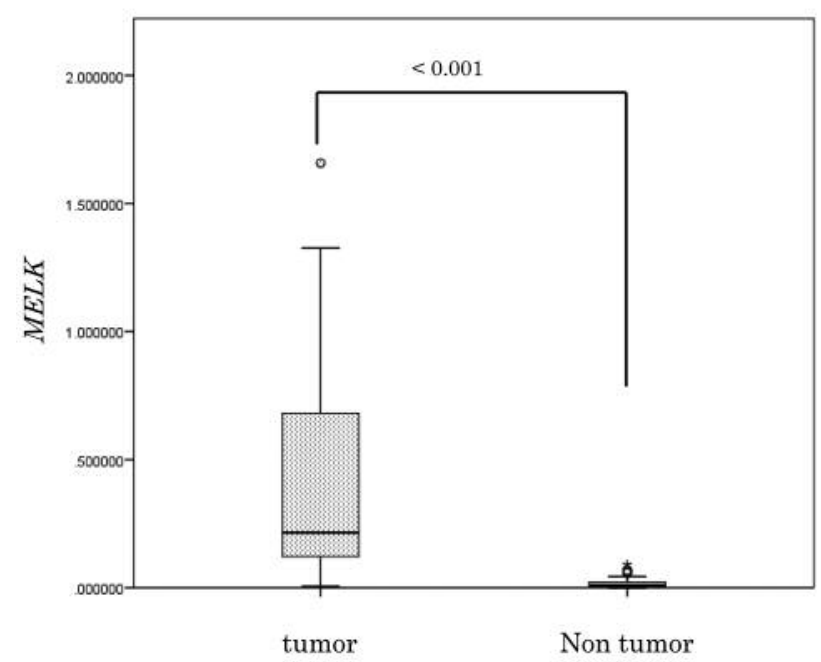

Figure 2. Comparing the quantitative expression of MELK $m R N A$ in paired cancer and non-cancerous tissues from 30 cases, HCC tissues exhibited significantly higher expression levels compared to noncancerous tissues. Unpaired t-test.

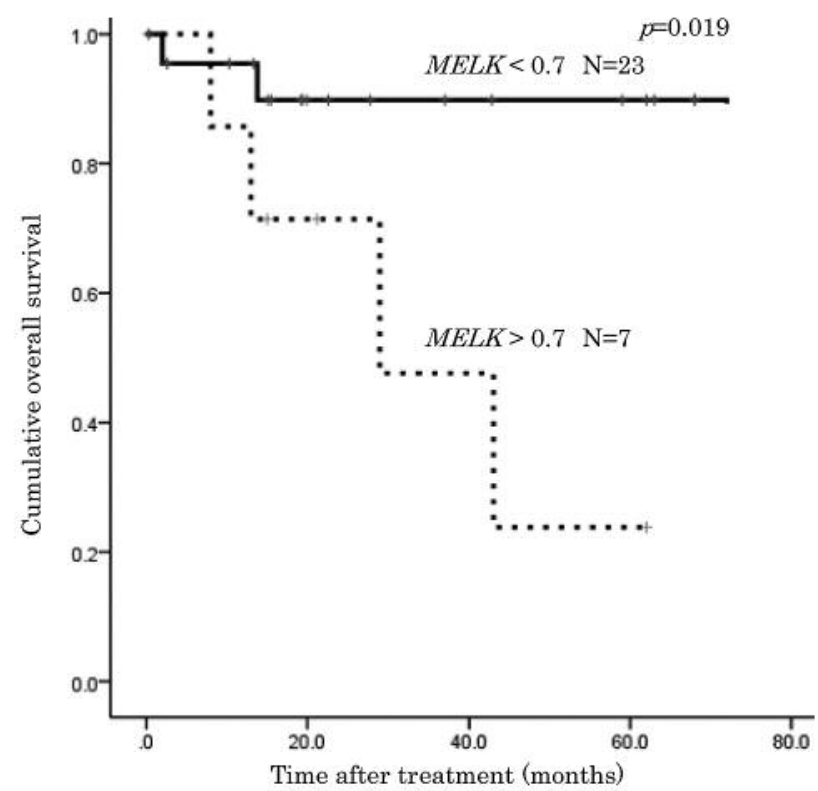

Figure 3. At a cut-off value of 0.7, RFS (median survival=42.3 months vs. 11.0 months) of the low MELK mRNA expression group was significantly longer than that of the high MELK MRNA expression group. Kaplan-Meier method, tested using the log-rank test.

enrichment of tumorsphere formation in culture and tumor initiation after transplantation (33). In addition, the transcription factor and oncogene FOXM1 formed a protein complex with MELK. Moreover, the transgenic expression of FOXM1 enhanced neurosphere formation using mouse neural progenitor cells and suggested that FOXM1-MELK binding

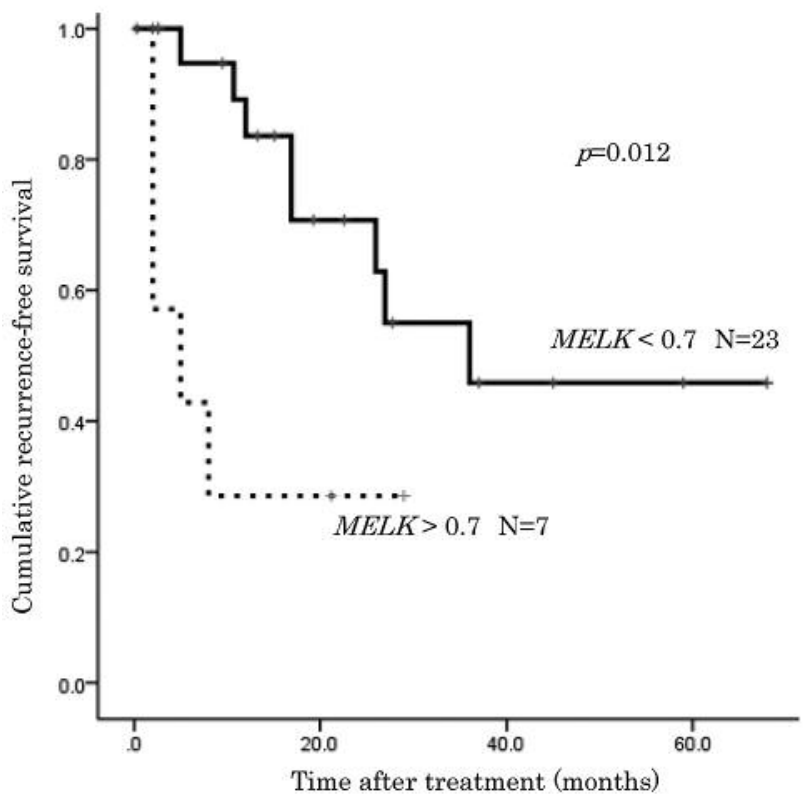

Figure 4. At a cut-off value of 0.7, OS (median survival=65.5 months vs. 34.9 months) of the low MELK mRNA expression group was significantly longer than that of the high MELK mRNA expression group. KaplanMeier method, tested using the log-rank test.

was required for neural progenitor cell growth (25). Therefore, MELK is associated with the basis of cell proliferation, including cancer progression.

Regarding the relationship between human cancers and MELK, Pickard et al. reported that MELK controlled apoptosis through Fau, a novel apoptosis regulator. Additionally, MELK expression was elevated in breast cancer tissue and this increase was also associated with poor patient survival (11). Similarly, Wang et al. reported that increased levels of MELK expression was detected in particularly aggressive subtypes of breast cancer (e.g., basal-like breast cancer) and correlated with poor prognosis (34). Du et al. reported MELK-associated cell cycle and elevated expression levels in human gastric cancer and found associated with chemoresistance (35). Marie et al. found progressively higher MELK expression associated with the astrocytoma grade. This study also revealed a noteworthy uniformity of high levels of expression in glioblastoma multiforme. The knockdown of MELK in malignant astrocytoma cell lines resulted in a reduction in proliferation and anchorage-independent growth as demonstrated by in vitro assays (10).

These reports coincide with our results that HCC tissues exhibited significantly higher expression levels compared to non-cancerous tissues $(p<0.001$, Figure 2) and MELK mRNA expression was significantly higher in advanced tumor stages ( $p=0.005$; Table I) and had a tendency to be 
Table I. MELK mRNA expression and clinicopathological features.

\begin{tabular}{|c|c|c|c|c|}
\hline \multicolumn{2}{|l|}{ Variable } & \multicolumn{2}{|l|}{$M E L K$ mRNA } & \multirow{2}{*}{$\frac{p \text {-Valu }}{<0.001}$} \\
\hline $\begin{array}{l}\text { Tumor/non-tumor } \\
\text { Fatty liver }\end{array}$ & $0.436 \pm 0.437$ & $0.019 \pm 0.023$ & & \\
\hline Yes (4)/No (26) & $0.270 \pm 0.289$ & $0.457 \pm 0.443$ & & 0.423 \\
\hline Diabetes mellitus & & & & \\
\hline $\begin{array}{l}\text { Yes }(7) / \text { No }(23) \\
\text { Alcohol consumption }\end{array}$ & $0.602 \pm 0.564$ & $0.387 \pm 0.384$ & & 0.247 \\
\hline $\begin{array}{l}\text { Yes }(5) / \text { No }(25) \\
\text { ICGR } 15 \geq 10 \%\end{array}$ & $0.462 \pm 0.203$ & $0.429 \pm 0.461$ & & 0.878 \\
\hline $\begin{array}{l}\text { Yes }(22) / \mathrm{No}(8) \\
\mathrm{AFP} \geq 10 \mathrm{ng} / \mathrm{ml}\end{array}$ & $0.404 \pm 0.465$ & $0.578 \pm 0.358$ & & 0.374 \\
\hline $\begin{array}{l}\text { Yes(20)/No(10) } \\
\text { PIVKA II } \geq 40 \mathrm{mAU} / \mathrm{ml}\end{array}$ & $0.433 \pm 0.433$ & $0.437 \pm 0.441$ & & 0.980 \\
\hline $\begin{array}{l}\text { Yes }(21) / \text { No }(9) \\
\text { Tumor size } \geq 3.75 \mathrm{~cm}\end{array}$ & $0.539 \pm 0.487$ & $0.196 \pm 0.093$ & & 0.047 \\
\hline $\begin{array}{l}\text { Yes }(15) / \text { No }(15) \\
\text { Tumor numbers } \geq 2\end{array}$ & $0.625 \pm 0.462$ & $0.246 \pm 0.323$ & & 0.015 \\
\hline $\begin{array}{l}\text { Yes }(11) / \text { No }(19) \\
\text { Tumor stage }\end{array}$ & $0.502 \pm 0.553$ & $0.398 \pm 0.366$ & & 0.538 \\
\hline $\begin{array}{l}\text { I, II (17)/III, IV (13) } \\
\text { Virus }\end{array}$ & $0.624 \pm 0.478$ & $0.290 \pm 0.207$ & & 0.005 \\
\hline None (18)/B (4)/C (8) & $0.523 \pm 0.458$ & $0.753 \pm 0.528$ & $0.386 \pm 0.478$ & 0.815 \\
\hline $\begin{array}{l}\text { Pathological parameter } \\
\text { Macroscopical type; } \\
\text { Simple nodular type }\end{array}$ & & & & \\
\hline $\begin{array}{l}\text { Yes (13)/No (17) } \\
\text { Microscopical type; }\end{array}$ & $0.280 \pm 0.292$ & $0.555 \pm 0.498$ & & 0.088 \\
\hline $\begin{array}{l}\text { Well (6)/moderately }(23) / \text { poor }(1) \\
\text { Infiltration to blood vessel }\end{array}$ & $0.470 \pm 0.415$ & $0.483 \pm 0.571$ & $0.335 \pm 0.469$ & 0.778 \\
\hline Yes (14)/No (16) & $0.555 \pm 0.444$ & $0.332 \pm 0.418$ & & 0.167 \\
\hline
\end{tabular}

Data are presented as number, percent and median \pm standard deviation, tested using the unpaired $t$-test. AFP, $\alpha$-Fetoprotein; ICGR15, indocyanine green retention rate at $15 \mathrm{~min}$; PIVKA II, protein induced by vitamin K absence or antagonist II. Pathological parameter is classified by the General Rules for the Clinical and Pathological Study of Primary Liver Cancer the 6th Edition (Liver Cancer Study Group of Japan).

lower for simple nodular types $(p=0.088$; Table I), which was the less aggressive type of the pathological parameters. The OS and RFS of the low MELK mRNA expression group were significantly longer than that of the high MELK mRNA expression group (Figures 3 and 4). MELK expression correlates to malignant potential and this study is the first report that examined MELK expression in HCC.

\section{Conclusion}

In summary, MELK is up-regulated in various types of cancer and our data also show MELK expression in HCC is up-regulated. Furthermore, MELK expression in HCC is extremely intense compared to previously reported types of cancer as MELK is involved in multiple protein interactions affecting many situations of tumorigenesis and cancer initiation. Therefore, MELK could be a promising effective tumor marker and a therapeutic target of HCC that could be used clinically in the near future.

\section{References}

1 El-Serag HB and Mason AC: Rising incidence of hepatocellular carcinoma in the United States. N Engl J Med 340: 745-750, 1999.

2 Bosch FX, Ribes J and Borras J: Epidemiology of primary liver cancer. Semin Liver Dis 19: 271-285, 1999.

3 El-Serag HB: Epidemiology of viral hepatitis and hepatocellular carcinoma. Gastroenterology 142: 1264-1273, 2012.

4 Japan Ministry of Health, Labor and Welfare carried out in 2008

5 Gil M, Yang Y, Lee Y, Choi I and Ha H: Cloning and expression of a cDNA encoding a novel protein serine/threonine kinase predominantly expressed in hematopoietic cells. Gene 195: 295-301, 1997.

6 Blot J, Chartrain I, Roghi C, Philippe M and Tassan JP: Cell cycle regulation of $\mathrm{pEg} 3$, a new Xenopus protein kinase of the KIN1/PAR-1/MARK family. Dev Biol 241: 327-338, 2002.

7 Lizcano JM, Göransson O, Toth R, Deak M, Morrice NA, Boudeau J, Hawley SA, Udd L, Mäkelä TP, Hardie DG and Alessi DR: LKB1 is a master kinase that activates 13 kinases of the AMPK subfamily, including MARK/PAR-1. EMBO J 23: 833-843, 2004.

8 Chung S, Suzuki H, Miyamoto T, Takamatsu N, Tatsuguchi A, Ueda K, Kijima K, Nakamura Y and Matsuo Y: Development of an orally- 
administrative MELK-targeting inhibitor that suppresses the growth of various types of human cancer. Oncotarget 3: 1629-1640, 2012.

9 Gray D, Jubb AM, Hogue D, Dowd P, Kljavin N, Yi S, Bai W, Frantz G, Zhang Z, Koeppen H, de Sauvage FJ and Davis DP: Maternal embryonic leucine zipper kinase/murine protein serinethreonine kinase 38 is a promising therapeutic target for multiple cancers. Cancer Res 65: 9751-9761, 2005.

10 Marie SK, Okamoto OK, Uno M, Hasegawa AP, Oba-Shinjo SM, Cohen T, Camargo AA, Kosoy A, Carlotti CG Jr, Toledo S, Moreira-Filho CA, Zago MA, Simpson AJ and Caballero OL: Maternal embryonic leucine zipper kinase transcript abundance correlates with malignancy grade in human astrocytomas. Int $\mathbf{J}$ Cancer 122: 807-815, 2008.

11 Pickard MR, Green AR, Ellis IO, Caldas C, Hedge VL, Mourtada-Maarabouni M and Williams GT: Dysregulated expression of Fau and MELK is associated with poor prognosis in breast cancer. Breast Cancer Res 11(4): R60, 2009.

12 Kuner R, Falth M, Pressinotti NC, Brase JC, Puig SB, Metzger J, Gade S, Schafer G, Bartsch G, Steiner E, Klocker H and Sultmann H: The maternal embryonic leucine zipper kinase (MELK) is upregulated in high-grade prostate cancer. J Mol Med (Berl) 91(2): 237-248, 2013.

13 Choi $\mathrm{S}$ and $\mathrm{Ku}$ JL: Resistance of colorectal cancer cells to radiation and 5-FU is associated with MELK expression. Biochem Biophys Res Commun 412(2): 207-213, 2011.

14 Liver Cancer Study Group of Japan. The General Rules for the Clinical and Pathological Study of Primary Liver Cancer

15 Heyer BS, Warsowe J, Solter D, Knowles BB and Ackerman SL: New member of the Snf1/AMPK kinase family, Melk, is expressed in the mouse egg and preimplantation embryo. Mol Reprod Dev 47: 148-156, 1997.

16 Heyer BS, Kochanowski H and Solter D: Expression of Melk, a new protein kinase, during early mouse development. Dev Dyn 215: 344-351, 1999.

17 Gu C, Banasavadi-Siddegowda YK, Joshi K, Nakamura Y, Kurt $\mathrm{H}$, Gupta S and Nakano I: Tumor-specific activation of the CJUN/MELK pathway regulates glioma stem cell growth in a p53-dependent manner. Stem Cells 31: 870-881, 2013.

18 Seong HA and Ha H.: Murine protein serine-threonine kinase 38 activates p53 function through Ser15 phosphorylation. J Biol Chem 287: 20797-20810, 2012.

19 Nishitoh H, Saitoh M, Mochida Y, Takeda K, Nakano H, Rothe M, Miyazono K, Ichijo H, Imamura $\mathrm{H}$ and Sano K: ASK1 is essential for JNK/SAPK activation by TRAF2. Mol Cell 2: 389395, 1998 .

20 Chang HY, Nishitoh H, Yang X, Ichijo H and Baltimore D: Activation of apoptosis signal-regulating kinase 1 (ASK1) by the adapter protein Daxx. Science 281: 1860-1863, 1998.

21 Saitoh M, Nishitoh H, Fujii M, Takeda K, Tobiume K, Sawada $\mathrm{Y}$, Kawabata M, Miyazono $\mathrm{K}$ and Ichijo $\mathrm{H}$ : Mammalian thioredoxin is a direct inhibitor of apoptosis signal-regulating kinase (ASK) 1. EMBO J 17: 2596-2606, 1998.

22 Liu H, Nishitoh H, Ichijo $\mathrm{H}$ and Kyriakis JM: Activation of apoptosis signal-regulating kinase 1 (ASK1) by tumor necrosis factor receptor-associated factor 2 requires prior dissociation of the ASK1 inhibitor thioredoxin. Mol Cell Biol 20: 2198-2208, 2000.

23 Song JJ, Rhee JG, Suntharalingam M, Walsh SA, Spitz DR and Lee YJ: Role of glutaredoxin in metabolic oxidative stress. Glutaredoxin as a sensor of oxidative stress mediated by $\mathrm{H}_{2} \mathrm{O}_{2}$. J Biol Chem 277: 46566-46575, 2002.
24 Park HS1, Cho SG, Kim CK, Hwang HS, Noh KT, Kim MS, Huh SH, Kim MJ, Ryoo K, Kim EK, Kang WJ, Lee JS, Seo JS, Ko YG, Kim S and Choi EJ: Heat shock protein hsp72 is a negative regulator of apoptosis signal-regulating kinase 1 . Mol Cell Biol 22: 7721-7730, 2002.

25 Joshi K, Banasavadi-Siddegowda Y, Mo X, Kim SH, Mao P, Kig C, Nardini D, Sobol RW, Chow LM, Kornblum HI, Waclaw R, Beullens $M$ and Nakano I: MELK-dependent FOXM1 phosphorylation is essential for proliferation of glioma stem cells. Stem Cells 31: 1051-1063, 2013.

26 Kim AH, Khursigara G, Sun X, Franke TF and Chao MV: Akt phosphorylates and negatively regulates apoptosis signalregulating kinase 1. Mol Cell Biol 21: 893-901, 2001.

27 Gu C, Banasavadi-Siddegowda YK, Joshi K, Nakamura Y, Kurt $\mathrm{H}$, Gupta $\mathrm{S}$ and Nakano I: Tumor-specific activation of the CJUN/MELK pathway regulates glioma stem cell growth in a p53-dependent manner. Stem Cells 31: 870-881, 2013.

28 Badouel C, Chartrain I, Blot J and Tassan JP: Maternal embryonic leucine zipper kinase is stabilized in mitosis by phosphorylation and is partially degraded upon mitotic exit. Exp Cell Res 316: 2166-2173, 2010.

29 Nakano I, Paucar AA, Bajpai R, Dougherty JD, Zewail A, Kelly TK, Kim KJ, Ou J, Groszer M, Imura T, Freije WA, Nelson SF, Sofroniew MV, Wu H, Liu X, Terskikh AV, Geschwind DH and Kornblum HI: Maternal embryonic leucine zipper kinase (MELK) regulates multipotent neural progenitor proliferation. J Cell Biol 170: 413-427, 2005.

30 Horvath S1, Zhang B, Carlson M, Lu KV, Zhu S, Felciano RM, Laurance MF, Zhao W, Qi S, Chen Z, Lee Y, Scheck AC, Liau LM, Wu H, Geschwind DH, Febbo PG, Kornblum HI, Cloughesy TF, Nelson SF and Mischel PS: Analysis of oncogenic signaling networks in glioblastoma identifies ASPM as a molecular target. Proc Natl Acad Sci USA 103: 17402-17407, 2006.

31 Lin ML, Park JH, Nishidate T, Nakamura Y and Katagiri T: Involvement of maternal embryonic leucine zipper kinase (MELK) in mammary carcinogenesis through interaction with Bcl-G, a pro-apoptotic member of the Bcl-2 family. Breast Cancer Res 9: R17, 2007.

32 Ganguly R, Mohyeldin A, Thiel J, Kornblum HI, Beullens M and Nakano I: MELK-a conserved kinase: Functions, signaling, cancer, and controversy. Clin Transl Med doi: 10.1186/s40169014-0045-y, 2015.

33 Hebbard LW, Maurer J, Miller A, Lesperance J, Hassel J, Oshima RG and Terskikh AV: Maternal embryonic leucine zipper kinase is upregulated and required in mammary tumorinitiating cells in vivo. Cancer Res 70: 8863-8873, 2010.

34 Wang Y, Lee YM, Baitsch L, Huang A, Xiang Y, Tong H, Lako A, Von T, Choi C, Lim E, Min J, Li L, Stegmeier F, Schlegel R, Eck MJ, Gray NS, Mitchison TJ and Zhao JJ: MELK is an oncogenic kinase essential for mitotic progression in basal-like breast cancer cells. Elife doi: 10.7554/eLife.01763, 2014.

35 Du T, Qu Y, Li J, Li H, Su L, Zhou Q, Yan M, Li C, Zhu Z and Liu B: Maternal embryonic leucine zipper kinase enhances gastric cancer progression via the FAK/Paxillin pathway. Mol Cancer doi: 10.1186/1476-4598-13-100, 2014.

Received August 4, 2016

Revised August 22, 2016 Accepted August 23, 2016 